will not be averse to buying American supplies if they can be persuaded that such supplies are desirable and suitable, but their wholly human disposition will be to buy their goods in the market from which their enterprise is financed and from suppliers with whom and with whose products they are best acquainted. We may buy up all the mortgages and bonds of a railway or any other company and it will not help us in the least so far as exporting merchandise to that company, its associates or its neighbors is concerned.

Even our present Edge Act, professedly designed to assist in the development of our export trade through the creation of agencies able to give us more adequate export credit facilities, specifically prohibits - as it now stands -banks organized under that Act from dealing in the shares of foreign corporations. Edge Act banks can only deal in bonds and mortgages, and whatever foreign securities the Edge Act banks may handle under the provisions of the present law will not directly affect one cent's worth of export trade for the United States. It is only through the actual control of a property that its policy can be dictated.

The one great lesson for us to learn, so far as I see it, in reviewing British methods, is the need of more thorough training of American business men for foreign work, and for a longer, more practical and more comprehensive apprenticeship of our young men in export work. The development of the organizations of American merchants in foreign countries will very likely be promoted as time passes, knowledge increases, and funds attracted to this sort of development become more easy. The more thorough training for foreign trade is a serious and imperative necessity. I am not now referring to courses in foreign trade, which fortunately are becoming more and more common in our universities and even in our high schools. They are thoroughly desirable so far as they go. Supplementing them there must be a longer and more practical apprenticeship in the actual conduct of commerce in its day by day routine and many different aspects. We work rather rapidly in the United States; too fast by far. We have extended our characteristic half-baked efforts to our export trade expansion. All sorts and conditions of young men have been attracted to the export "game," as they lightly term it, and men of all sorts and conditions have been sent abroad to represent American interests, more often than not with no or little adequate training. Real and great success is not thus to be obtained.

\title{
Difficulties of Financing Export Trade
}

\author{
By Francis II. Sisson \\ Vice-President, Guaranty Trust Company of New York
}

$\mathrm{T}$ THERE is perhaps not a very clear understanding by the public in general of the functions and the limitations of service of the international banks in relation to our export trade. This is plainly indicated by the suggestions that are now made by certain un- informed critics that in some way these banks are not "supporting" this trade adequately.

It seems that such a charge ignores the primary fact of the relation of banks to our foreign commerce. Their essential interest and profit must al- 
ways lie in rendering the utmost assistance to overseas trade that it is possible for them to give--safely, and within the limitations imposed by law upon their operations. The word "safely" is of paramount significance. This factor of safety must receive the first consideration by banking officers, if they are to be true to their obligations as guardians of the property of others.

The funds which are the basis of any aid to commerce that banks may give are the demand deposits of their clients, and this demand quality of commercial banking funds at once fixes very definite limits to the use that may be made of them. It positively excludes their employment in any large amount for loans of a term longer than three or four months. Hence, the utmost care nuust be exercised to assure that advances made upon the basis of commercial transactions with foreign countries shall have more than a reasonable probability of liquidation within the term for which these loans are agreed upon.

The most frequent form of aid extended to export trade by a commercial bank is through the discount of drafts covering sales of goods abroad, these drafts maturing at a definite date - usually not exceeding four months from the time when they are discounted. The collateral held by banks to protect such loans usually consists of merchandise in transit to the foreign buyer, held under the control of the lending bank through possession of bills of lading and other documents by its trusted agents, either in its own branch banks abroad or in correspondent banks with which it holds close, continuing relations. When all goes smoothly, these drafts are paid, as they fall due, to the foreign agents of the American bank and the loan is liquidated by the transfer of the proceeds to the lending company, or by a credit through the open accounts which international banks throughout the world maintain with one another.

Thus, an active bank at any given date may have hundreds, or even thousands, of outstanding loans on foreign trade transactions, some of which are due and paid every day and, in consequence, afford a renewed supply of funds for new transactions. When times are good and there are no clouds upon the horizon of trade, this system of revolving credit functions uninterruptedly and to the advantage of all concerned, and we hear little complaint of indifference on the part of banks to demands. It is when the movement we have described is checked -as it is today-that doubt rises in some minds as to whether the banks are doing their full duty in the situation.

As a matter of fact, however, it is the bank that first of all feels the shock of any stoppage to the normal functioning of this credit system. When drafts are not paid by foreign buyers, the bank at once finds itself holding an overdue and unpaid loan and also is burdened with the responsibility for collateral, which it must handle to the best possible advantage of the American shipper and to the protection of its own equity in it. The seller, who has discounted his draft, is already in possession of his money, although it is true that he is liable to the bank in the event that his draft is unpaid. He is also liable if the proceeds of collateral sold do not fully cover the amount of the loan involved. When, as today, in markets throughout the whole world there is cancellation of contracts, refusal to accept shipments or to pay drafts, the immediate result is to tie up banking funds in very large amounts and to burden the banks with the problems incident to the care and disposal of shipments upon which funds have been advanced. 
How seriously this may cripple their ability to continue their normal volume of loans to their American clients should be recognized readily enough. When, in addition to cancellations and protest of drafts, there are added to the situation the factors of falling prices, depreciated exchange and flooded markets, it is clear that the difficulties confronting the banks are real enough. Moratoria and embargoes exist in certain countries and are threatened in others. Forced sales of shipments are extremely difficult-impossible in many cases. Banks are handicapped in their power to serve their clients to the degree that their resources are involved in those transactions in which prompt liquidation has failed of consummation.

Sound business principles must preclude the officers of any bank from extending their commitments unduly when such international trade conditions arise. They must keep their house in order, and, until these temporarily non-liquid loans are brought into liquid form again, the utmost care must be exercised lest the rights of the demand depositors should be jeopardized. A commercial bank must recognize its obligation to avoid, if possible, any loan transactions that will involve it for undetermined periods of time. Long-term loans are the affair of the investment banker and are not for the international commercial bank to handle. This distinction should be fully comprehended by the public and, when understood, will serve to refute the criticisms to which we have referred.

The present world situation is admittedly a difficult one. The banks are as much concerned as any branch of business in finding a solution for these problems and are committed by selfinterest to the support of any policiessafe policies - that will aid to bring back better conditions. All that should be asked of the banks is that they "carry on" with prudence and contribute every particle of effort, in the way of expert technical knowledge to the encouragement of steadfast confidence, that they can offer under trying conditions. It would not help at all to adopt unsound banking practices during a term of stress. It would merely add to any dangers that already exist.

The world today looks to the United States as the one solidly fortified nation in the realm of finance and trade. No other country has to a like extent the great power needed to meet the present emergencies. This fact is receiving general and a constantly extending degree of recognition in our own country. We have come to realize thoroughly that Europe must have food, raw materials and machinery before she can hope to return to normal health in finance and trade, and that she must have a considerable time extended to her before she can pay for these products. We recognize that this implies thrift and the saving of investment funds in large amounts here in order that they may be available in rehabilitating the industries of Europe.

Many now see that depreciated exchange can be restored only through Europe's resumption of normal production and exporting. We know that great markets for our own raw products are now stagnant because of idle factories in France, Germany, Italy and elsewhere. Furthermore, markets in South America and the Orient, which would otherwise be absorbing our manufactured products continuously, are stricken for the same reason. Their products, wheat and wool, hides and skins, and metals, which normally are in urgent demand in Europe, move but slowly. The whole intricate machinery of world trade is clogged by the prostration of economic life in the countries so seriously devastated by the war. 
This economic life must be quickened promptly.

Since the armistice, the minds of men in all parts of our country have had time to comprehend the course of events and the meaning and needs of the present critical period. As with the war itself, full realization has been slow in spreading among the people. It is by no means universal now. Leaders do exist, however, and others, with the international outlook, will no doubt be effective in stimulating the action that seems to be required. There are evidences of clear recognition of the demands of the situation in many quarters.

In response to the growing demands for adequate means to meet the situation, Congress has revived the War Finance Corporation, and it is hoped that this action may be efficacious. But the Federal Reserve Board, in a recent analysis of the foreign and domestic credit situation, stated:

.It is not only desirable but practically essential that satisfactory arrangements be made for the financing of a legitimate and reasonable export trade, such action facilitating, as it necessarily will, the restoration of industry abroad and, consequently, the eventual liquidation of the claims which we now hold upon foreign countries. Such long-term advances, however, should be financed through the agency of actual investment credits provided by the placing of bonds or other evidences of indebtedness in the hands of individuals or institutions who are in position to supply the funds that are needed to "carry" these obligations until their foreign recipients are able to settle them.

In the South, the cotton interests are preparing to sell their product abroad and to finance sales by longterm loans through corporations organized under the new Edge Act. Most significant of all is the recent meeting in Chicago, where a powerful group of bankers decided to organize a one hun- dred million dollar corporation under the same Act. This proposed corporation is to be devoted specifically to promoting foreign trade by means of long-term investment loans. Large as will be the corporation that is planned, and its resources would imply operations involving more than one billion dollars in credits, it will not be too large for the urgent present demands.

The method by which credits will be established is simple enough, although the problem of selecting acceptable collateral abroad for loans is one that will require high technical skill and sound judgment. Such loans as may be made will be in the form of dollar credits in American banks, available to pay for goods exported to the borrowers.

The question as to how far the investing public will absorb the debentures based upon this collateral of foreign securities and other properties still remains to be answered. The answer will depend largely upon how thoroughly the American people understand that their own prosperity is involved in such a movement. It is encouraging to note that the subscriptions to the New Orleans Edge Law corporation have been promptly made and are ample in amount.

The strength of the banking interests behind the Chicago plan should inspire confidence. When the public understands that the proposed investments abroad will, in effect, act as a priming to force into full action the now halting machinery of world trade, immediately creating markets for stocks that are now moving slowly or not at all, there should be a country-wide response when subscriptions for Edge Law debentures are offered. Every classmerchant, manufacturer, farmer and laborer-should be interested.

This method of aiding Europe partakes in no way of the character of 
charity. This form of help is sane, selfrespecting and businesslike, and is apparently the most effective way by which manufacturers and merchants abroad may obtain the equipment and supplies that will permit them, in due time to liquidate their debts here in full.

\title{
Improvements in British Empire Trade Information- The Imperial Statistical Conference
}

\author{
By R. H. Conts \\ Dominion Statistician, Ottawa
}

\begin{abstract}
A outline of recent improvements $A$ in British Empire trade information may take as a starting-point the Dominions Royal Commission, appointed in 1912. The Commission had its origin in a resolution of the Imperial Conference of the previous year, its instructions being to report comprehensively on the natural resources and production of the Empire, with special reference to the possible improvement and extension of InterImperial trade. It consisted of eleven members, six representing the United Kingdom and one each, Canada, Australia, New Zealand, the Union of South Africa and Newfoundland.
\end{abstract}

A very searching investigation extending over a period of five years and embracing all sections of the Empire was conducted by the Commission. Its report, which was in several volumes, covered a great variety of subjects of industrial and commercial interest. Certain of the volumes dealt in a general way with specific Dominions; others assembled the data regarding raw materials, trade, transportation and the like for the Empire as a whole. Incidentally, a considerable impetus to statistical investigation was given in the preparation of memoranda for the Commission's use; in fact, when the Commission finally disbanded, which was at a date when the war was absorbing all of the available energy of the Dominions, the immediately im- portant result was the comprehensive array of information which it had assembled against the return of normal conditions.

The perpetuation of these materials and the keeping of them up to date was naturally one of the prominent recommendations of the Commission's report. In its travels throughout the Empire, a feature strongly borne in upon the Commission was the incomparability of the official statistics of the several Dominions, as well as the discrepancies and omissions which characterized specific fields.

The situation was set forth in considerable detail in the report, and the suggestion made that there should be summoned forthwith a Conference of the official statisticians of the Empire, with a view to the improvement of existing conditions where possible, and the drawing up of a scheme of statistical coördination for the Empire as a whole. The rider was added that a central statistical bureau for the Empire should be set up, with a view to the maintenance of such scheme of coördination as might be agreed upon, and for the periodical collection, compilation and dissemination of comparative data of economic interest to the Empire.

The second recent step forward in the improvement of British Empire trade information may be considered as the meeting in London during the winter of 1920 of the conference of stat- 